\title{
STUDI DAMPAK PEMBERDAYAAN SISTEM KEUANGAN SYARIAH AL-IJARAH BAGI PELAKU UMKM
}

\author{
Umrotul Khasanah'1, Meldona², Muhammad Djakfar³ \\ 1,2,3 Universitas Islam Negeri Maulana Malik Ibrahim Malang, Indonesia
}

$\triangle$ Corresponding Author:

Nama Penulis: Umrotul Khasanah

E-mail: umrotul_kh@yahoo.com

\section{Abstract}

Al-Ijarah's Islamic Financial System has produced strategic results. The Islamic financial system to differentiate from conventional financial systems based on interest (interest), the Islamic financial instrument is the al-ijarah (lease) system. This study aims to reveal the impact of Micro, Small, and Medium Enterprises (MSME) business actors on the Islamic financial system using the alijarah instrument; reveal the effect of business land managers leased to MSMEs regarding the Islamic financial system using the al-ijarah instrument. This research puts forward a qualitative descriptive research method with case studies of culinary business actors and providers of land for rent in Malang Raya, East Java. Data analysis uses a gradual approach, namely: analyzing important statements, formulating, describing, reducing data towards findings, propositions, and conclusions. The researcher, as the main instrument, performs data analysis simultaneously. Researchers prioritize observation and interviews. This research found two things: (1) Al-Ijarah business actors successfully overcame obstacles and obstacles. However, they initially applied their abilities as they were, but they could use their management skills quite well after developing. (2) The benefits for entrepreneurs who provide business / al-ijarah land leases are that they are successful in delivering strategic places, easy to reach, availability of parking spaces, and security aspects.

Key words: Syariah Finance System; MSMEs; Al-Ijarah

\section{Abstrak}

Sistem Keuangan Syariah Al-Ijarah ternyata membuahkan hasil strategis. Sistem keuangan syariah untuk membedakan dengan sistem keuangan konvensional yang berbasis bunga (interest), instrumen keuangan syariah tersebut adalah sistem al-ijarah (sewa). Penelitian ini bertujuan untuk mengungkap dampak pelaku bisnis Usaha Mikro, Kecil dan Menengah (UMKM), terhadap sistem keuangan syariah dengan instrumen al-ijarah; menyingkap dampak pengelola lahan bisnis yang disewakan kepada kalangan UMKM tentang sistem keuangan syariah dengan instrumen al-ijarah. Penelitian ini mengedepankan metode penelitian deskriptif kualitatif dengan studi kasus terhadap pelaku bisnis kuliner dan penyedia lahan bisnis yang disewakan di Malang Raya, Jawa Timur. Analisis data menggunakan pendekatan bertahap, yaitu: menganalisa pernyataan penting, merumuskan, mendeskripsikan, mereduksi data menuju temuan, proposisi dan kesimpulan. Peneliti sebagai instrumen utama melakukan analisis data secara simultan. 
Umrotul Khasanah: Studi Dampak Pemberdayaan Sistem Keuangan Syariah

Peneliti memprioritaskan observasi dan wawancara. Penelitian ini menemukan dua hal: (1) Pelaku bisnis al-Ijarah berhasil mengatasi rintangan dan hambatan, walaupun awalnya mereka menerapkan kemampuan dengan apa adanya, namun setelah berkembang mereka dapat mengaplikasikan kemampuan manajemen dengan cukup baik. (2) Dampak manfaat bagi pengusaha yang menyediakan persewaan lahan bisnis/al-ijarah, bahwa mereka berhasil menyediakan tempat strategis, gampang dijangkau, tersedianya tempat parkir dan aspek keamanan

Kata kunci: Sistem Keuangan Syariah; UMKM; Al-Ijarah

\section{PENDAHULUAN}

Keberadaan Usaha Mikro, Kecil dan Menengah (UMKM) menjadi strategis dan sentral dalam konteks pembangunan ekonomi nasional di Indonesia. Gambaran ideal UMKM tersebut bisa nampak dalam pergolakan sejarah ekonomi nasional. Sebagaimana kasus yang menimpa perekonomian Indonesia dalam gelombang krisis ekonomi dan moneter tahun 1998, sektor UMKM yang ternyata berdiri kokoh dan tidak terpengaruh dengan adanya gelombang krisis tersebut, bahkan bisa dikata sektor UMKM sebagai penyelamat pembangunan ekonomi nasional.

UMKM mempunyai peran yang sangat menonjol pada pasca krisis ekonomi dan moneter tahun 1998. Kontribusi UMKM dalam perekonomian merupakan yang paling besar dibanding dengan pelaku bisnis lainnya terutama kalau kita bandingkan dengan bisnis usaha besar. Pada tahun 2011 kontribusi UMKM terhadap negara mencapai 61,9 persen dalam bentuk Produk Domestik Bruto (PDB). Besaran PDB itu dapat diperinci sebagai berikut: sektor usaha mikro berkontribusi 36,28 persen, sektor usaha kecil berkontribusi 10,9 persen dan sektor usaha menengah 14,7 persen. Jika hal itu dibandingkan dengan bisnis usaha besar yang kontribusi PDB mencapai 38,1 persen, maka UMKM kemampuan PDB-nya hampir dua kali lipat bisnis usaha besar (BPS, 2011).

Jika kita melihat posisi UMKM yang mendekati krisis moneter yaitu pada tahun 2003, BPS juga memberikan catatan positif bagi UMKM (BPS 2003). BPS menyatakan kinerja UMKM menunjukkan trend positif, terutama dalam hal besaran Produk Domestik Bruto (PDB) pada tahun 2003 UMKM memberikan kontribusi sebesar Rp 1.013,5 triliun yang setara 56,7 persen terhadap PDB. Meskipun pasca diterjang krisis, kondisi UMKM jauh lebih baik dari pada usaha konglomerasi. Dalam kondisi Krismon tersebut, jumlah unit usaha UMKM pada tahun 2003 masih bertahan tegar tidak terpengaruh krisis. Jumlah UMKM kita pada saat itu masih mencapai sekitar 42,4 juta dan dari puluhan juta unit usaha tersebut, UMKM dapat menyerap tenaga kerja 79,0 juta pekerja. 
Umrotul Khasanah: Studi Dampak Pemberdayaan Sistem Keuangan Syariah

Melihat betapa besarnya jasa UMKM, sudah semestinya negara memberikan perhatian seperti diskresi terhadap UMKM agar "Laskar Mandiri" tersebut dapat berbuat lebih baik lagi dan lebih berperan secara dominan dalam perekonomian. Namun bentuk perhatian semacam tersebut ternyata belum terlihat signifikan. Meskipun ada ternyata cenderung verbalisme, belum tertera secara nyata dalam bentuk kebijakan yang dapat dinikmati oleh UMKM. Setidaknya hal itu, bisa terlihat dalam beberapa catatan penelitian yang masih memberikan catatan kurang mengembirakan.

Sebagai misal apa yang dinyatakan oleh Wijono (2005) secara keseluruhan belum ada perlakuan khusus maupun memberi perhatian secara khusus terhadap UMKM. Pemerintah cenderung membiarkan UMKM tumbuh secara apa adanya. Dalam penelitian tersebut diungkap bahwa UMKM masih berada dalam posisi yang memprihatinkan yang mempunyai banyak kelemahan secara fundamental sebagai berikut: (1) sulitnya produk-produk UMKM menembus pasar, (2) lemahnya dalam pengembangan dan penguatan usaha, (3) keterbatasan akses terhadap sumber-sumber modal, terutama dari kalangan perbankan. Untuk memberikan bantuan yang solutif terhadap UMKM agar tidak jalan ditempat, maka pendekatannya tidak bisa dilakukan secara parsial atau sendiri-sendiri, perlu tindakan yang terintegratif, dan yang mesti menjadi perhatian pokok adalah akses UMKM terhadap modal.

Fakta penelitian yang diungkap tersebut memberikan pemahaman pada peneliti bahwa negara masih memberi perlakuan yang kurang adil terhadap UMKM, terutama dalam perlakuan dan pemberian fasilitas akses keuangan terhadap UMKM. Seharusnya, pemerintah mengambil hikmah dari tragedi ekonomi tahun 1998 pada waktu terjadinya krisis ekonomi tersebut.

Menurut Tetanel (2008), posisi krusial bagi Indonesia itu disebabkan oleh pengaruh kebijakan moneter internasional dan kebijakan domestik yang tidak berpihak ke UMKM. Dalam dua dasawarsa terakhir Indonesia telah didekte oleh dua lembaga keuangan internasional, yaitu IMF dan World Bank. Indonesia melakukan kebijakan tidak populis seperti menghapus atau mengurangi subsidi, menurunkan tarif impor komoditi pangan terutama bahan pokok seperti beras, terigu, gula dan lainnya. Ismail (2011) terjadinya marginalisasi terhadap UMKM disebabkan oleh kebijakan yang tidak berpihak pada kalangan kelas menengah ke bawah. Terutama yang berkaitan dengan kebijakan moneter Bank Indonesia (BI).

Saat ini sudah ada perhatian yang mendalam untuk membantu UMKM, namun karena proses pemberian kebijakan khusus itu harus menempuh mekanisme kebijakan politik, seringkali realisasi dari kebijakan tersebut terdistorsi oleh kepentingan politik tertentu. Karena itu, agar fasilitas akses keuangan terhadap UMKM tepat sasaran, perlu ada "diskresi" atau perlakuan khusus terhadap UMKM. Hal yang tak kalah penting adalah agar 
Umrotul Khasanah: Studi Dampak Pemberdayaan Sistem Keuangan Syariah

pemerintah menjaga konsistensi antara kebijakan pemerintah dan realisasinya di lapangan agar tidak salah sasaran. Pada hakikatnya program pemberian akses keuangan terhadap UMKM adalah merupakan amanat Pancasila dan UUD 1945, yaitu mewujudkan perekonomian nasional yang mencerminkan spirit keadilan dan pemerataan distribusi perekonomian nasional dalam semua lapisan strata sosial ekonomi.

Korea Selatan dan Taiwan merupakan negara Asia yang telah berhasil mendorong UMKM-nya naik kelas menjadi usaha menengah yang tangguh sebagai penopang utama perekonomian nasionalnya. Kebijakan dan program-program yang dilakukan dua negara tersebut hendaknya bisa dijadikan peta jalan (road map) bagi kebijakan agar dapat mendorong UMKM.

Melihat tantangan masa mendatang, yang sebenarnya kita sudah memasuki era Masyarakat Ekonomi Asean (MEA) dan pada gilirannya akan terintegrasi pula pada pasar global. Maka, dalam hal ini masyarakat Indonesia harus jujur mengakui belum cukup siap memasuki fase pasar tunggal Asean tersebut. Terutama jika melihat keberadaan UMKM, karena masih buruknya pemberian fasilitas yang diberikan pemerintah akibat akses terhadap modal yang sangat minim. Karena minimnya fasilitas keuangan dari pemerintah, yang memberikan akses modal di kalangan usaha kecil dan mikro adalah lembaga keuangan informal dan formal yang bersifat nonperbankan. Merekalah yang mendominasi dalam pemberian fasilitas pembiyaan bagi kalangan usaha kecil dan mikro. Karena badan hukumnya bersifat informal, maka tidak ada regulasi yang memayunginya dan aturan mereka buat sendiri sehingga perilakunya cenderung tidak adil dan merugikan para UMKM. Sebagai contoh dalam pengenakan bunga, mereka mematok bunga yang cukup tinggi di kisaran 20\%-30\% bahkan bisa sampai $40 \%$. Banyak pedagang kecil yang jadi korban, akibat sistem bunga berbunga, akhirnya banyak yang menderita bangkrut dan tidak bisa melanjutkan aktifitas berdagangnya lagi (Khasanah 2016).

Indikasi ketidaksiapan UMKM kita memasuki era MEA dengan terintegrasinya pasar dan produksi menjadi pasar tunggal Asean justru terletak pada kinerja keuangan UMKM itu sendiri. Karena minimnya akses modal yang difasilitasi pemerintah, sehingga kinerja keuangan UMKM mengalami kesulitan dalam bergerak. Sedangkan kunci sukses sektor UKM kita berintegrasi masuk secara sehat dalam pasar tunggal MEA adalah terletak pada keunggulan kompetitif (Competitive advantage). Persoalannya Competitive advantage itu akan dicapai kalau kinerja keuangan baik, karena melakukan hal itu harus memiliki strategi bersaing dan melakukan inovasi secara terus menerus (Terziovski, 2002). Masyarakat ekonomi Indonesia akan terintegrasi dengan lingkungan bisnis yang lebih besar, yaitu 
Umrotul Khasanah: Studi Dampak Pemberdayaan Sistem Keuangan Syariah

masyarakat ekonomi Asia-Pacific. Ciri pokok dari dua lingkungan bisnis besar tersebut adalah liberalisasi perdagangan dan liberalisasi investasi. Artinya semua area lingkungan bisnis pada dua fase tersebut mau tidak mau akan terjadi leberalisasi, maka di sini akan terjadi "hukum besi ekonomi" siapa yang siap dan kuat akan mendominasi perekonomian.

\section{KAJIAN PUSTAKA}

\section{Moral Ekonomi Konvensional vs Ekonomi Syariah}

Pandangan atau filosofi dasar dari suatu ilmu amat berpengaruh dalam praktik perekonomian (Ayub, 2009). Dalam konteks ini, yang senantiasa tidak pernah lepas dari perdebatan adalah masalah-masalah yang melingkupi perekonomian yaitu isu soal moral atau etika bisnis. Pandangan ekonomi konvesional sangat berpengaruh pada sosok atau costume dari praktik konvensional yaitu terwujudnya praktik sistem berbasis bunga (interest). Sementara pandangan ekonomi Islam, dalam hal moral atau etika justru mengeritik keras bahwa praktik bunga amatlah tidak adil dalam praktik bisnis, sebab praktik bunga mengokohkan pandangan bahwa manusia pada hakikatnya adalah mahkhluk ekonomi dengan kredonya "siapa yang kuat akan memangsa yang lemah". Dari sinilah pandangan ini mengindasikan secara kuat bahwa sistem yang demikian akan berpontensi mewujudkan masyarakat akan terjadi gap sosial: yang kaya makin kaya, yang miskin makin miskin.

Dampak dari pemberlakuan basis moral atau etika bisnis konvensional terus menerus menimbulkan kontroversi dan secara praktik menimbulkan anomali-anomali atau penyimpangan dari idealisme awalnya. Perekonomian yang sejatinya dibangun untuk menyejahterakan masyarakat para pelakunya, malah menimbulkan dampak sebaliknya, perekonomian bergerak bersamaan dengan meningkatnya kemiskinan dan kesenjangan sosial. Perwujudan nilainilai konvensional yang demikian secara universal sangat tidak diharapkan bagi umat manusia di seantero jagad ini. Sebagai turunan dari teori ekonomi konvensional, pada level praktik ada yang mengeritik keras bahwa teori pertumbuhan ekonomi sekarang ini, ternyata melahirkan anomali-anomali, yaitu pertumbuhan ekonomi tidak berdampak secara signifikan terhadap kesejahteraan rakyat, pengentasan kemiskinan, penghapusan kesenjangan sosial ekonomi dan penghapusan pengangguran.

Maka ketika teori pertumbuhan tidak berjalan sebagaimana mestinya dalam kenyataan pembangunan ekonomi suatu negara, gugatan akan segera muncul agar mengganti teori tersebut dengan sistem alternatif lainnya. Dewasa ini, gaung gugatan terhadap teori pertumbuhan yang merupakan derivasi dari sistem kapitalis tersebut datang dari masyarakat lokal, tetapi 
Umrotul Khasanah: Studi Dampak Pemberdayaan Sistem Keuangan Syariah

gugatan ke arah sistem kapitalisme semakin keras berbunyi dalam tataran global. Hal itu terjadi, karena sistem kapitalisme tidak mampu memberikan solusi yang tepat untuk mengatasi krisis ekonomi yang muncul. Sistem ekonomi konvensional ternyata tidak mempunyai sistem antibodi atau kekebalan yang mujarab untuk mengatasi penyakit ekonomi yang datang dari dalam tubuhnya sendiri. Padahal suatu teori yang dikatakan mapan adalah teori yang pada dirinya serba komplit untuk mengatasi persoalan sesuai dengan ruang lingkupnya dan juga terdapat sistem kekebalannya.

Berdasarkan kajian dan pengamatan yang dilakukan (Abdullah \& Chee, 2010) sistem ekonomi konvensional setidaknya sudah tiga kali tidak mampu menghadapi tekanan krisis ekonomi global. Krisis ekonomi global tersebut masing-masing terjadi pada tahun 1973 berupa krisis minyak, kemudian pada 11 September 2001 pada saat krisis karena serangan teroris dan krisis keuangan global di AS pada tahun 2008. Terutama setelah terjadinya krisis keuangan global tahun 2008 yang bermula di AS, makin banyak pakar yang meragukan kemampuan sistem ekonomi konvensional untuk mengatasi krisis ekonomi yang ada. Di tengah-tengah kegalauan para ekonom dan elit dunia untuk mengatasi krisis ekonomi itulah, sistem ekonomi Islam memberikan tawaran alternatif dan diikuti berbagai rentetan bukti-bukti empirik bahwa yang kebal terhadap krisis ekonomi global ternyata industriindustri keuangan yang memakai sistem ekonomi Islam. Sistem ekonomi Islam akhirnya menjadi mainstream sebagai sistem ekonomi alternatif. Semua ini terjadi, setelah sistem ekonomi konvensional mengalami kebuntuan dan tidak mampu mengatasi krisis ekonomi tersebut sehingga sistem keuangan Islam menjadi alternatifnya.

Lebih lanjut menurut (Abdullah \& Chee, 2010), kelebihan sistem ekonomi Islam dibanding dengan konvensional adalah sistem ekonomi Islam mempunyai daya imun yang kuat dan mempunyai daya stabilitas dalam menghadapi krisis keuangan global. Kuatnya daya imun dan daya stabilitas tersebut karena sistem keuangan Islam telah dilengkapi dengan fondasi filosofis yang kokoh. Kekokohan fondasi sistem keuangan Islam tersebut karena ditegakkan dengan lima prinsip dasar, yaitu: dasar keimanan sebagai pedoman, bebas bunga (riba), diharamkan berinvestasi untuk barang haram, bersifat sharing risiko dan mendasarkan pembiayaannya pada asset riil. Sistem keuangan Islam merepresentasikan ide bahwa semua manusia dan pemerintahan merupakan subyek untuk menegakkan keadilan perekonomian.

\section{Instrumen Keuangan Islam al-Ijarah}

Secara etimologis al-ijarah adalah bay'ul manfa'ah (menjual manfaat). Kata al-ijarah berdasarlkan ilmu sharraf (ilmu yang mempelajari proses 
Umrotul Khasanah: Studi Dampak Pemberdayaan Sistem Keuangan Syariah

terbentuknya kata) ijarah berasal dari fi'il madli "ajara - ya'juru - ajran" yang artinya upah, sewa, imbalan atau ganti. Secara terminologi al-ijarah dapat didefinisikan sebagai transaksi atas manfaat sesuatu barang atau jasa yang ditukar atau diganti dengan imbalan tertentu yang diperbolehkan secara syari'ah (Choudhury \& Hussain, 2005). Maka, obyek yang ditransaksikan di sini adalah adanya "manfaat" atau adanya hak guna dari suatu barang.

Berdasarkan uraian tersebut, maka dasar hukum atau dalil diberbolehkannya al-ijarah sehingga transaksinya menjadi halal, merujuk pada dalil qauliyah, yaitu al-Qur'an dan Hadits, ijmak dan qiyas. Kemudian juga merujuk pada dalil qauniyah, yaitu secara logika atas fakta sosial yang ada bahwa manusia dalam upaya memenuhi kebutuhan hidupnya seharihari. Berdasarkan kedua dasar dalil tersebut, maka muncullah suatu postulat bahwa menjadi keniscayaan bagi manusia untuk saling berinteraksi dan saling tolong-menolong dalam upaya memenuhi kebutuhan hidupnya seharihari.

Para ulama fiqih menguraikan masalah ekonomi mu'amalah ini dalam satu bab khusus yang disebut "al-Bab al-Buyu" atau "al-Bab al-Muamalat", karena ulama membaginya ke dalam dua pembahasan, yaitu Fiqih Ibadah dan Fiqih Muamalah. Al-buyu' menurut Bahasa Arab adalah bentuk jamak dari kata al-bay'. Alasan para fuqoha' memberi nama al-buyu' yang bentuk jamak dari al-bay', karena untuk menunjukkan bahwa bentuk transaksi jualbeli itu beraneka ragam atau begitu beragamnya jenis jual-beli.

Menurut (Al-Asqalani, 2007) di dalam Kitab Fathul Bari menyatakan bahwa pada dasarnya makna al-bay' adalah menjual. Sebaliknya makna dari Asy-Syira' adalah membeli. Sedangkan secara syara', al-bay' dapat dirumuskan sebagai proses memindahkan kepemilkan kepada orang lain dengan bayaran harga tertentu. Sementara Asy-Syira' secara syara' didefinisikan menerima kepemilikan yang dipindahkan tersebut. Meski demikian, yang berlaku di kalangan orang Arab dalam kehidupan sehari-hari, Asy-Syira' maupun al-bay' merujuk pada maksud yang sama, yaitu dimaksudkan sebagai ekspresi jual-beli.

Kata-kata al-bay' merupakan derivasi yang terambil dari ayat dalam alQur'an pada Surat al-Baqarah ayat 275: "Dan Allah menghalalkan jual-beli (al-bay') dan mengharamkan riba". Kemudian dalil kebolehan al-bay' berdasarkan Hadits Nabi, yaitu yang berbunyi "Nabi SAW pernah ditanya, "Pekerjaan apakah yang paling baik (halal)? Nabi SAW menjawab: "Pekerjaan seorang lelaki yang dilakukan oleh tangannya sendiri, dan setiap transaksi albay' (jual-beli) yang mabrur,".

Kehalalan transaksi jual-beli, disamping berdasarkan dalil naqli yaitu nash al-Qur'an dan al-Hadits, juga berdasarkan dalil aqli, yaitu secara logika. 
Umrotul Khasanah: Studi Dampak Pemberdayaan Sistem Keuangan Syariah

Menurut Al-Asqalani (2007) dasar pemikirannya adalah bahwa dalam kehidupan sehari-hari manusia harus memenuhi kebutuhan hidupnya, sementara kebutuhan tersebut tidak mungkin cukup hanya dipenuhi dari kepemilikannya sendiri. Karena sebagian besar kebutuhan seseorang ada pada kepemilikan orang lain. Sedangkan orang lain tidak mungkin memberikan kepemilikan tersebut secara gratis. Karena itulah dibutuhkan media untuk menjembatani pemenuhan kebutuhan hidup manusia, yaitu lewat instrument jual-beli (al-bay').

Sedangkan pengertian al-bay' menurut Zainuddin bin Abdul Azis alMalibari al-Fannani (2006) dalam "Kitab Fathul Mu'in" adalah menukar sesuatu dengan sesuatu -- yang lain - (muqaabalatu syai'in bisy-syai'in). Secara syara' ulama mendefinisikan al-bay' menukar sejumlah harta dengan harta (yang lain) dengan cara sesuai ketentuan syari'ah Islam.

Baik dalam ayat al-Qur'an maupun al-Hadits terdapat kata-kata: "mengharam riba" (al-Qur'an) dan "jual-beli yang mabrur" (al-Hadits). Ijma' ulama menjelaskan masalah ini adalah bahwa di dalam jual-beli ada yang dilarang atau diharamkan yaitu transaksi ribawi, segala transaksi yang berbau riba. Sedang dalam menjelaskan jual-beli mabrur, ulama menjelaskan bahwa jual-beli itu tidak boleh ada unsur penipuan dan pengkhiatan.

Syaikh al-Imam al-Alim al-Allamah Syamsuddin Abu Abdillah Muhammad bin Qasim as-Syafi'i (1983) di dalam "Kitab Fathu al-Qarib" menjelaskan transaksi jual-beli itu, harus memenuhi tiga syarat, yaitu: (1) Barang yang diperjual-belikan adalah benda suci. (2) Barang yang diperjualbelikan tersebut dapat diambil manfaatnya sesuai yang dimaksud. (3) Barang yang ditransaksikan dapat diterimakan atau dapat diserahkan kepada pihak pembeli. Maka ulama menghukumi sah terhadap jual-beli barang-barang yang suci dan dapat diambil manfaatnya. Dan menghukumi haram terhadap barang jual-beli yang najis seperti tuak atau minuman keras atau mutanajjis (barang terkena najis) seperti minyak parfum yang tak mungkin menyucikannya. Juga tidak sah jual-beli barang yang tak ada manfaatnya seperti binatang kala, semut dan binatang buas yang tak dapat diambil manfaatnya.

Dasar hukum antara al-ijarah dan jual-beli merujuk pada dalil yang sama yaitu tentang kebolehan al-bay', namun secara praktik dan implikasinya berbeda (Ashari \& Saptana, 2005). Kalau al-bay' obyek transaksinya adalah hak kepemilikan barang, dengan kata lain setelah transaksi al-bay' hak kepemilikan barang pihak penjual akan pindah kepada pihak pembeli. Sedang dalam transaksi al-ijarah yang berpindah bukan hak kepemilikan barang, namun hanya hak manfaat atau hak guna/pakai saja yang berpindah, dari pihak pemberi sewa kepada pihak yang menyewa. Jumhur ulama fiqih menyatakan bahwa al-ijarah adalah transaksi menjual 
Umrotul Khasanah: Studi Dampak Pemberdayaan Sistem Keuangan Syariah

manfaat, sehingga yang boleh disewakan hanya manfaatnya bukan bendanya. Karena itulah, ulama mengharamkan transaksi menyewakan pohon untuk diambil buahnya. Juga dilarang menyewakan sapi atau domba untuk diambil susunya. Begitu juga diharamkan menyewakan kolam untuk diambil ikannya. Karena transaksi yang demikian sudah termasuk kategori al-bay', proses transaksi yang menyebabkan berpindahnya hak kepemilikan barang, bukan hanya manfaatnya.

\section{METODE}

Penelitian ini menggunakan paradigma sosial. Penelitian ini tidak saja menelusuri hubungan sebab dan akibat sebagaimana berlaku dalam penelitian "fakta sosial" melainkan juga berupaya mencari pemahaman yang lebih mendalam. Weber menyebutnya sebagai versetehen, yaitu upaya memahami secara lebih dalam, khususnya terhadap realitas sosial. Untuk memahami secara lebih dalam dan menyeluruh, jelas tidak cukup dengan hanya melihat aspek hubungan sebab akibat dari beberapa variabel yang diajukan, melainkan juga harus digali makna, nilai-nilai, pemahaman yang lebih mendalam tentang manfaat sistem keuangan syariah al-ijarah dalam pemberdayaan pelaku UMKM yang memanfaatkan lahan-lahan sewaan di Malang Raya yang dipraktikkan pelaku bisnis UMKM tersebut. Melalui paradigma ini dapat diperoleh pemahaman lebih mendalam sebagaimana dikehendaki dalam penelitian ini.

Selain itu, penelitian ini juga sengaja memilih pendekatan kualitatif yaitu jenis pendekatan penelitian yang tidak saja berambisi mengumpulkan data dari sisi kuantitasnya (Bungin, 2010), tetapi sekaligus ingin memperoleh pemahaman lebih mendalam di balik fenomena sosial yang berhasil direkam untuk diteliti. Mengungkap cara pandang praktik ijarah yang dilakukan oleh pelaku binis UMKM yang memanfaatkan lahan-lahan bisnis yang disewakan di Malang Raya, bagaimana pengelola lahan bisnis sewaan dalam mempraktikkan sistem al-ijarah, dan secara keseluruhan manfaat pemberdayaan apa saja yang dapat dirasakan dengan memakai instrumen keuangan syariah al-ijarah dalam menyejahterakan para pelaku bisnis UMKM tersebut. Hal tersebut yang cukup kompleks dipandang lebih tepat diteliti dengan pendekatan kualitatif untuk memperoleh jawaban yang lebih bersifat mementingkan aspek kedalaman, dan bukan hanya berorientasi pada keluasan cakupannya.

Walaupun begitu, data-data kuantitatif juga digunakan. Angka-angka statistik yang menggambarkan perbandingan pencapaian perilaku ekonomi, sebab penelitian ini juga memperhatikan aspek pengumpulan data kuantitatif 
Umrotul Khasanah: Studi Dampak Pemberdayaan Sistem Keuangan Syariah

seperti berupa besaran-besaran angka pendapatan kaum pedagang, jumlah permasalahan sosial yang ada di lokasi penelitian.

\section{HASIL DAN PEMBAHASAN}

\section{Pandangan Pelaku Bisnis tentang Sistem Keuangan Syariah al-Ijarah}

Pelaku Bisnis Usaha Mikro Kecil dan Menengah (UMKM) tidak homogen. Mereka berlatarbelakang yang majemuk, ada yang awalnya memulai dari jadi sopir, kuli bangunan, tukang parkir, karena diajak teman dan sebagainya. Mereka yang awalnya memulai dari usaha jasa loundry, kemudian masuk ke dalam bisnis warung nasi. Tidak terlalu lama menunggu, akhirnya ia menjadi pengusaha restoran besar. Omsetnya pun mencapai miliaran rupiah.

Nanang (31 tahun) misalnya, Bisnis responden tersebut sudah masuk ke jajaran pelaku bisnis miliaran rupiah. Jaringan restorannya kini sudah masuk 60-an restoran. Hampir di setiap kota yang ada di Pulau Jawa sudah terdapat jaringan bisnisnya. Rumahnya sudah masuk kalangan menengah ke atas. Disamping dilengkapi dengan asesoris yang mewah, juga terdapat kolam renangnya. Kendaraannya juga bervariasi, mulai dari sepeda motor yang jumlahnya lebih dari satu. Demikian juga fasilitas mobilnya, jumlahnya juga lebih dari satu dan variasinya: mulai dari pick up, truk, mobil penumpang mulai dari yang sederhana sampai mobil yang mewah seperti Alphard.

Nanang memulai bisnisnya dengan cara yang sederhana. Waktu itu, dia masih kuliah dengan usia masih 20 tahunan. Karena sebelum kuliah dia belajar di Pondok Pesantren selama 6 tahun. Waktu di pesantren, dia memasak sendiri, sehingga ketika di Malang, melihat teman-temannya ratarata makan di warung. Akhirnya, dia menawari teman-temannya untuk dimasakkan. Awalnya hanya satu dua, tapi lama-lama semakin banyak.

Setelah kira-kira mencapai 20 orang yang ingin dilayani, maka dia membuka usaha warung. Kemudian yang bersangkutan menikahi seseorang yang juga mempunyai hobi memasak. Suami istri ini lantas membuka warung dengan mengaplikasikan sistem keuangan syari'ah al-ijarah. Lahan bisnis yang disewa, mereka mencari yang berada di tempat yang ramai. Keluarga muda ini merumuskan strategi bisnis dan model marketing yang harus dilakukan dengan modal apa adanya.

Sebagai usaha bisnis pemula, karena orang tuanya bukan dari kalangan pengusaha, maka ide dan gagasan pasangan muda ini yang jadi andalannya. Tahun awal sampai tahun ketiga banyak kendala bisnis yang dihadapi. Beruntung pernah hidup di dunia pesantren, yang sedikit banyak bisa membantu dalam menghadapi tantangan dan rintangan dunia bisnis. Keterampilan bersabar dan ulet serta sikap kreatif tak pernah berputus asa 
Umrotul Khasanah: Studi Dampak Pemberdayaan Sistem Keuangan Syariah

adalah modal utama yang diandalkan untuk memecahkan hambatan bisnis. Secara bertahap perusahan yang dibangun menjadi perusahaan yang cukup besar dan sudah punya nama di kalangan pengusaha kuliner di Jawa Timur.

Sikap yang sama dilakukan oleh Supardi (35 tahun), walaupun sudah belasan tempat bisnis yang dikelola, belum satu tempat bisnis pun yang milik pribadi. Semua lahan bisnisnya masih milik orang, pihaknya mengaplikasikan sistem keuangan syari'ah yaitu al-Ijarah. Ada yang sistem sewanya bulanan dan ada pula yang sewanya tahunan. Rata-rata harga sewanya per tempat Rp 15 juta per tahun.

Awal membuka usahanya tidak punya karyawan, yang memasak adalah istrinya, sedang dia sendiri yang melayani konsumen dan memasarkan usahanya. Kalau masih satu warung, dikelola sendiri masih bisa diatasi. Namun ketika warungnya terus bertambah, menjadi tak terhindarkan lagi dia harus merekruit karyawan. Kini karyawannya sudah mencapai 60 orang, rata-rata gajinya mereka per bulannya Rp 1.200.000,- .

Setelah punya banyak karyawan, dirinya dan istrinya sekarang ini hanya sebagai pengontrol dan pengendali. Semua jaringan memakai manajemen dengan kantor pusat pengendalian di rumahnya. Manajemen yang mengendalikan, dia hanya mengontrol secara keseluruhan. Para karyawannya bekerja sesuai dengan tugas masing-masing. Warung-warung jaringannya ada di masing-masing kampus, terutama kampus-kampus besar seperti Unmuh, Unisma, UM, UB dan Polinema. Ada beberapa faktor yang mendorong orang untuk menjadi pengusaha, di antaranya sebagai tertarik sendir, diajak teman, meniru orang, ingin sukses.

\section{Opini Pengelola Bisnis terhadap Sistem Keuangan Islam al-Ijarah}

Tak hanya pihak pelaku bisnis kuliner yang berkepentingan memelihara kondisi pasar. Pengusaha yang menyediakan lahan bisnisnya untuk disewa atau objek al-Ijarah juga berkepentingan. Karena pada hakikatnya mereka juga bersaing. Model desain bangunannya juga selalu diperbaharui sesuai dengan trend yang ada. Tempatnya juga harus strategis, yaitu harus dekat dengan kampus dan ada akses jalan yang gampang untuk dikunjungi. Begitu juga tersedianya tempat parkir yang memadai agar pengunjung yang sedang menikmati kuliner tidak gelisah dan khawatir ketika sedang menikmati kuliner.

Andry (45 tahun) punya lahan sekitar $1000 \mathrm{~m} 2$, lokasinya ada di perempatan jalan belakangan kampus UIN Maliki Malang. Posisi lahan bisnisnya termasuk strategis berdekatan empat kampus yaitu UIN Maliki Malang, UB, Uniga dan ITN Malang. Meski bukan jalur utama, tetapi jalan yang melintas di situ juga merupakan jalur angkutan umum mikrolet. 
Umrotul Khasanah: Studi Dampak Pemberdayaan Sistem Keuangan Syariah

Pada awalnya, Andry juga membuka warung yaitu makanan ringan seperti mie dan minuman, terutama es kelapa muda. Dengan membuka warung dan loundry atau mencuci pakaian sebenarnya sudah mencukupi untuk memberi nafkah keluarganya. Hanya saja, karena dia punya lahan bisnis yang belum terpakai dan banyak orang yang meminta kepada dia agar lahannya dibangun berupa warung-warung untuk menjadi stand bisnis kuliner.

Setelah dibangun dengan model-model yang memadai dan desainnya disesuaikan dengan era sekarang. Lahan yang tidak begitu luas itu akhirnya dibangun dengan model bangunan petak-petak warung menjadi 20 warung. Sewa lahan warung di situ satu warung Rp 1 juta perbulan.

Menyewakan lahan bisnis, buat Andry ternyata menjadi bisnis yang mengasyikan. Tidak perlu mengeluarkan modal tiap hari, pengeluaran pertama saja yang lumayan banyak yaitu untuk membangun petak-petak warung itu. Pengeluarannya untuk membeli material bangunan dan ongkos tukangnya menghabiskan dana sekitar Rp 2 miliar. Dia hanya membangun petak warungnya saja, mengenai isi terserah pada orang yang menyewa.

Bisnis sewa lahan ini sudah berjalan hampir sepuluh tahun. Andry yang merupakan sarjana ekonomi dari Universitas Negeri Jember ini, tidak pernah melamar kerja. Karena begitu dia sudah sarjana, oleh orang tuanya langsung diwarisi lahan bisnis yang strategis itu. Pengetahuan sarjananya yang kebetulan ekonomi itu, cukup membantu wawasan dia untuk mengembangkan lahan bisnisnya.

Sementara itu Sulalah (50 tahun) adalah dosen UIN Malang yang kini menjadi Ketua Holding Company (HC) UIN Maulana Malik Ibrahim Malang juga menyediakan lahan bisnis untuk disewakan untuk warung nasi. Kebetulan UIN Maliki Malang punya program untuk menyantrikan mahasiswanya selama satu tahun. Jumlahnya sekitar 3000 mahasiswa yang harus mondok di kampus. Karena ada program pesantrennya, maka pihak UIN Maliki Malang bekerjasama dengan masyarakat yang sekaligus untuk memberdayakan secara ekonomi. Ada sekitar 40 orang pedagang kuliner yang berjualan atau bisnis kuliner di UIN Maliki Malang.

UIN Maliki Malang dalam hal ini pengelola Holding Company (HC) menyewakan stand atau petak warung itu masing-masing dengan harga Rp 20 juta per warung setiap tahun. Warung-warung yang ada di UIN Maliki Malang disamping untuk memberikan konsumsi mahasiswa yang sedang nyantri, juga untuk warga kampus yang tidak mondok atau untuk umum. Makanan-makanan yang ditawarkan ke mahasiswa di UIN Malang termasuk murah, jika dibandingkan dengan di luar kampus UIN Maliki Malang. Satu piring atau satu porsi makan harganya Rp 6000 sampai dengan Rp 12.000. 
Umrotul Khasanah: Studi Dampak Pemberdayaan Sistem Keuangan Syariah

Harga sewa petak warung di UIN Maliki Malang tergolong murah jika dibanding di luar kampus UIN Maliki Malang. Misalnya saja jika dibanding dengan di Universitas Brawijaya, harga sewa lahan di situ bisa dua kali lipat dengan di UIN Maliki Malang. Karena, menurut Sulalah, UIN Maliki Malang memang mempunyai misi untuk memberdayakan pedagang yang ada di sekitar kampus. Konsumennya pun sudah jelas, yaitu terutama santri yang ada di UIN Maliki Malang.

Pengelola dalam hal ini pihak UIN Maliki Malang juga tidak dirugikan dengan adanya bisnis kuliner yang dilakukan masyarakat. Walaupun UIN Maliki Malang hanya mengenakan tarif yang murah, tetapi paling tidak itu sudah cukup menambahkan income bagi kampus. Kampus sendiri juga harus merekrut karyawan untuk menjaga kebersihan dan perawatan lahan bisnis tersebut.

Beberapa hal yang dirasakan sebagai keuntungan oleh kalangan pengelola lahan bisnis yang disewakan yaitu antara lain: membantu orang untuk mendapatkan pekerjaan, mendapat keuntungan yang memadai dengan menyewakan lahan bisnis, mahasiswa bisa dibantu disediakan tempat konsumsi, menambah fasilitas bisnis kuliner di sekitar kampus.

\section{KESIMPULAN}

Latar belakang pengusaha UMKM sangat beragam, mereka biasanya tidak langsung mendirikan warung, tetapi faktor pengalaman masa lalu merupakan faktor dominan yang menentukan keberhasilan bisnisnya. Kalau bukan pengusaha keturunan, pengusaha UMKM biasanya memulai karirnya dari bawah yang menghadapi banyak rintangan dan hambatan. Kemampuan untuk keluar dari berbagai rintangan dan hambatan menjadi modal signifikan untuk menjadi pengusaha sukses. Faktor mereka menjadi pengusaha bermacam-macam, ada yang awalnya tertarik sendiri, diajak teman, meniru orang dan rata-rata mereka ingin menjadi orang yang sukses. Awalnya, mereka rata-rata memulai usahanya dengan apa adanya, kemudian setelah usahanya mulai meningkat lambat laun mereka mengeterapkan manajemen secara profesional. Semakin rumit dan semakin banyak karyawannya, mereka semakin profesional sehingga akhirnya mereka hanya mengendalikan perusahannya lewat manajemen.

Bisnis usaha al-Ijarah ternyata tidak hanya menguntungkan pengusaha kuliner, tetapi pihak yang menyewakan lahan bisnis juga berkepentingan dengan berjalannya bisnis UMKM ini. Mereka juga bersaing dalam menjalankan bisnisnya. Untuk menang dan lahan bisnisnya disewa orang, mereka punya kiat-kiat bisnis untuk menarik para pelanggannya. Kiat-kiat yang dilakukan mereka antara lain, tempat lahan bisnis yang akan disewakan tersebut harus berada di daerah yang strategis. Kemudian selain itu, 
Umrotul Khasanah: Studi Dampak Pemberdayaan Sistem Keuangan Syariah

daerahnya gampang ditembus orang baik pejalan kaki maupun mereka yang pakai kendaraan bermotor. Yang terpenting juga adalah daerahnya aman dan ada tempat parkir yang memadai. Mereka juga membangun lahan bangunannya disesuaikan dengan trend yang sedang berlaku. Dengan kiatkiat bisnis seperti itu, maka persewaan lahan bisnis tersebut akan banyak peminatnya. Yang jelas dengan usaha persewaan tersebut ada beberapa faktor keuntungan yang mereka harapkan antara lain yaitu dapat membantu orang untuk mendapatkan kerjaan. Kemudian juga mendapat keuntungan yang memadai dengan menyewakan lahan bisnis, membantu mahasiswa untuk mendapatkan tempat konsumsi dan dapat menambah fasilitas bisnis kuliner di sekitar kampus.

\section{DAFTAR PUSTAKA}

Abdullah, D. V., \& Chee, K. (2010). Islamic Finance: Understanding its Principles and Practices . Singapore: Marshall Cavendish International. Al-Asqalani, A.-H. I. (2007). Bulugul Maram. Jakarta: AK-Barmedia.

Ashari, \& Saptana. (2005). Prospek Pembiayaan Syariah untuk Sektor Pertanian,. Forum Penelitian Agro Ekonomi, 23(2), 132-147.

Ayub, M. (2009). Understanding Islamic Finance, Aditya Wisnu Pribadi (penerjemah). Jakarta: PT. Gramedia Pustaka Utama.

Choudhury, Masudul A, and Hussain, Md. Mostaque, 2005, A Paradigm of Islamic Money and Banking, International Journal of Social Economics, 32(3), 203-217.

El-Komi, Muhammed Salah, 2010, Poverty: Allevation Through Microfinance and Implications on Education, Dissertation Doctor of Philosophy in Public Policy and Political Economy, The University of Texas at Dallas, AS.

Hafidhuddin, Didin, Tanjung, Hendri, 2003, Manajemen Syariah dalam Praktik, Gema Insani Press, Jakarta.

Hudayati, Ataina, 2009, Hubungan Sistem Pengendalian Manajemen dan Kinerja Pembiayaan Bagi Hasil serta Kinerja Bank Islam di Indonesia, Fenomena, 7(1), 215-227.

Kaleem, Ahmad and Abdul Wajid, Rana, 2009, Application of Islamic Banking Instrument (Bai Salam) for Agriculture Financing in Pakistan, British Food Journal, 3(3), 275-292.

Kanjuruhan, Media Informasi Pemerintah kabupaten Malang, Edisi JuliSeptember 2011, 24-27.

Karim, Rifaat AA and Ali, Amal El-Tigani, 1989, Determinants of The Financial Strategy of Islamic Banks, Journal of Business Finance \& Accounting, 16(2), 193- 212.

Khan, Ayesha Khalid, 2010, Essay on Faith and Islamic Finance, Dissertation Doctor of Business Administration, Harvard Bussiness School, Boston, Massachusetts, AS.

Khasanah, dkk. 2013, The Practice of Profit and Loss Sharing System For Rice Farmers in East Java Indonesia, IOSR Journals International 
Umrotul Khasanah: Studi Dampak Pemberdayaan Sistem Keuangan Syariah

Organization of Scientific Research, ISSN: 2278-487X, Mar-Apr 2013, 9(3), 01-07.

Kompas, 2011, Produksi Beras: Krisis Lahan Pertanian Pangan Terjadi, Kompas, 03 November 2011, 17.

Las, Irsal, Subagyono, K, dan Setiyanto, AP., 2006, Isu dan Pengelolaan Lingkungan dalam Revitalisasi Pertanian, Jurnal Litbang Pertanian, 25(3), 122-139

Miles, Matthew B and Huberman, A.Michael, 2009, Qualitative Data Analysis, Tjetjep Rohendi Rohidi (penerjemah), UI-Press, Jakarta.

Sajogyo, 2002, Pertanian dan Kemiskinan, Jurnal Ekonomi Rakyat, Th.1, No. 1, www.ekonomirakyat.org.

Shihab, M.Quraish, 2000, Wawasan Al-Quran, Cet, 11, Mizan, Bandung.

Tetanel, Yauri. 2008, Globalisasi dan Nasib Pertanian Indonesia, Seminar Nasional Kedaulatan Pangan Fateta UGM, 23 Agustus 2008.

Vogel, Frank E; Hayes, Samuel L, 1998, Islamic Law and Finance: Religion, Risk, and Return, Kluwer Law Internasional, The Hague-LondonBoston.

Yasin, Muhammad, 2008, Kebijakan “Kredit Panen” Sebagai Instrumen Guna Mengangkat Petani Padi Dari Kemiskinan, Jurnal Ichsan Gorontalo, $3(1)$. 